wieniach NMP Bernadecie Soubirous. Autorka z wielką pasją opisuje podobne koleje i wydarzenia, pokazując jak Maryja inspiruje twórczo i zmienia współczesny świat w niemal wszelkich dziedzinach życia i w różnych okresach historycznych, szczególnie traumy dwóch wojen światowych. I tak aż do naszych czasów.

Zaskakuje bardzo pozytywny wykład historyczny Autorki z protestanckiej Anglii, która z wielkim obiektywizmem i nie odrzucając wiary w N. M. Pannę oraz jej pozytywnego wkładu w rozwój cywilizacji chrześcijańskiej, ułożyła wielokolorową, bardzo bogatą mozaikę oddziaływania maryjnego na wszelkie dziedziny ludzkiego życia, od początków powstania chrześcijaństwa aż do dnia dzisiejszego. W trakcie czytania książki odczuwa się coraz większy szacunek i przyciąganie do maryjnego aspektu wiary chrześcijańskiej, a nawet wdzięczność za twórczy wkład Maryi w oblicze tego chrześcijaństwa.

Autorka wykazała się olbrzymią znajomością wiedzy historycznej i tradycji chrześcijańskiej do których podeszła z wielką pokorą i przygotowaniem, aczkolwiek można zauważyć jej źródłowe braki kultury krajów słowiańskich. Znana jest przecież na całym świecie maryjna pobożność Polaków oraz wizerunek Matki Boskiej Częstochowskiej, o których autorka w ogóle nawet nie wspomniała; pewnie nie miała do nich dostępu. Podobnie stosunkowo bardzo mało miejsca poświęciła wpływowi prawosławnej wizji Maryi na całą chrześcijańską kulturę Wschodu i Zachodu. Na szczęście mamy na ten temat ogromną literaturę, którą dobrze jest wciąż rozpowszechniać w obcojęzycznej literaturze tak, by później inni autorzy mogli z niej korzystać, dodając tym samym polski i prawosławny wkład maryjnego dziedzictwa w kształtowanie coraz to nowego oblicza chrześcijaństwa.

Ks. Ryszard Groń - Chicago, USA

\title{
Lisa M. BITEL, Landscape with Two Saints. How Genovefa of Paris and Brigit of Kildare built Christianity in Barbarian Europe, Oxford 2009, Oxford University Press, ss. 299.
}

Lisa Bitel, profesor historii, religii i studiów kulturowych nad różnicami płciowymi Uniwersytetu Południowej Karoliny w USA, specjalizuje się w badaniu wczesnego okresu historii i kultury średniowiecza Europy, szczególnie Irlandii. Obecna pozycja jest kolejną $\mathrm{z}$ tej dziedziny. Tym razem jednak zajęła się rzadko omawianym tematem, z racji bardzo skąpych wiadomości, a mianowicie postanowiła przedstawić twórczą rolę dwóch świętych niewiast: Genowefy z Paryża (422-502) i Brygidy z Kildare w Pd. Irlandii (452-524), jako budowniczych porządku chrześcijańskiego w barbarzyńskim okresie Europy (V-VI w.). Wybór tych świętych nie jest przypadkowy, albowiem ich żywoty są do siebie podobne, a ponadto mówi się o rzadkim i przemożnym wpływie obydwu niewiast na bieg historii chrześcijaństwa V i VI w. oraz kształtowanie się jego społeczeństwa, które na owe czasy było swoistym ewenementem (s. xii-xiii). Nie były one męczennicami, bo okres męczenników już generalnie minął, ale stały się swoistymi budowniczy- 
mi chrześcijańskiej Europy, zarówno w sensie duchownym jak i materialnym, na zgliszczach państwa rzymskiego i w okresie najazdów barbarzyńskich plemion.

Autorka podjęła się bardzo trudnego zadania, albowiem omawiane święte same nic nie napisały, a ponadto nie mogła polegać na wielu piśmiennych przekazach, które o nich traktowały. Pod tym względem, musiała się zadowolić żywotem św. Genowefy (Vita S. Genovefae, CPL 2104), spisanym przez anonimowego mnicha 20 lat po jej śmierci, prawdopodobnie z polecenia Klotyldy, żony ówczesnego władcy frankońskiego Chlodwiga; w drugim przypadku pozostał Żywot św. Brygidy (Vita S. Brigidae, CPL 2147, PL 72, 775-790) spisana ponad wiek później przez niejakiego mnicha imieniem Cogitosus z południowej Irlandii, gdzie żyła święta. Trudności dodaje fakt, że obydwa żywoty zostały spisane w stylu hagiograficznych pobożnych życiorysów, jakie w tym czasie obowiązywały, tzw. żywotów (vita), z których należało wyciągnąć dane biograficzne i oddzielić je od pobożnej tradycji obfitującej w wiele cudownych wydarzeń. Pod tym względem prof. L. Bitel prześledziła wspomniane utwory oraz inne wzmianki wcześniejszej i późniejszej tradycji oraz podparła się danymi historycznymi epok i regionów, w których żyły święte: w pierwszym przypadku - Paryża, w drugim - południowej Irlandii. Prześledziła przy tym szczegółowo całą historię obydwu miast oraz ich regionów aż do czasów życia świętych, a także przeanalizowała wszystkie architekturalne, liturgiczne pozostałości oraz źródła sztuki z nimi związane, jak: ruiny kościołów, których budowanie inicjowały, malowidła ścienne, rzeźby oraz pozostałą tradycję piśmienną. Tak powstał owoc pracy autorki w postaci obecnego dzieła.

Wspomniane niewiasty okazały się pobożnymi chrześcijankami dającymi twórczy impuls nowej duchowości i cywilizacji chrześcijańskiej. Inicjowały (prze)budowę (pogańskich) świątyń, zachęcały do życia w doskonałości chrześcijańskiej poprzez praktykowane ubóstwo, posłuszeństwo Kościołowi, wzór życia w czystości i umartwieniach, świadczenie dzieł miłosierdzia względem opuszczonych, potrzebujących i chorych, organizowanie życia zakonnego, szczególnie wśród kobiet, służenie duchowym i publicznym autorytetem ubogim i możnym tego świata, nie wyłączając biskupów i królów, organizowanie materialnej pomocy w obliczu kataklizmów i niebezpieczeństw. To wszystko sprawiło, że stały się one później lokalnymi symbolami chrześcijaństwa.

Na całość książki składa się 8 rozdziałów poprzedzonych, spisem treści, wykazem ilustracji, głównie map miejsc związanych ze świętymi oraz ich pomnikami czy atrybutami oraz wprowadzeniem autorki. Książkę kończą przypisy, bibliografia oraz indeks.

Rozdział I (Paris before Genovefa: the landscape enters history) opisuje losy Paryża oraz jego okolice przez narodzeniem Genowefy, czyli rzymskiej podległości oraz gallijskich, germańskich i frankońskich wpływów. Rozdział II (Sacral Paris) zajmuje się aspektem religijnym Paryża, jego kulturą pogańską, chrystianizacją, burzeniem pogańskich i budowaniem świątyń chrześcijańskich, w tym szczególną rolę biskupa Auxerre - Germanusa (ok. 418-466) w krzewieniu chrze- 
ścijaństwa. Rrozdział III (Genovefa s’ territory) jest poświęcony życiu i środowisku Genowefy, napisany na podstawie wspomnianego Vita. Rozdział IV (Paris after Genovefa) opisuje historię duchowego patronatu Genowefy nad miastem Paryż.

Pozostałe cztery rozdziały dotyczą drugiej omawianej tu świętej - Brygidy oraz środowiska południowo-irlandzkiego, z którego pochodziła. Zatem rozdział V (Crossings and controversions) wprowadza w zagadnienie chrystianizacji Irlandii przed V wiekiem i wpływów rzymsko-brytońskich. Rozdział VI (Ekphrasis at Kildare) omawia żywot św. Brygidy na podstawie utworu spisanego przez Cogitosusa w charakterze „,architekturalnej hagiografii” (ekphrasis), łączącej legendarno-historyczny życiorys świętej z początkami architektury kościelnej w Kildare, czyli pokazuje jej twórczy impuls na tle kształtującej się powoli religii chrześcijańskiej i architektury kościelnej, której dawała początki. Rozdział VII (Brigit goes to ground) demaskuje legendę i opisuje historyczne kolejne fazy niełatwego pochodu chrześcijaństwa w Irlandii Południowej za czasów Brygidy i po jej śmierci, oraz thumaczy jej autorytatywną rolę w późniejszych wiekach. Ostatni rozdział (Relics) opisuje losy relikwii (doczesnych szczątków i pozostałości po obydwu świętych), historyczne próby wymazania ich kultu wobec zaginięcia relikwii, wreszcie rehabilitację tego kultu w obliczu współczesnych badań.

Książka prof. L. Bitel pokazuje, że mamy do czynienia z nietuzinkowym badaczem historykiem, który nie daje łatwo wiary legendom i nie poddaje się wobec skąpych wzmianek historycznych. Można być zaskoczonym rozległością i fachowością jej badań nie tylko z zakresu historii, ale również literatury, antropologii, hagiografii czy architektury. Jako owoc jej wysiłku, powstała wspaniała praca, owoc jej kilkuletnich badań, która otwiera nowe sposoby patrzenia na starą wielowiekową tradycję: ta zaś każe widzieć w tych dwóch świętych niewiastach: Genowefie i Brygidzie, wyjątkowych budowniczych cywilizacji chrześcijańskiej Francji i Irlandii u ich początków. Pozostaje życzenie, by owoce tej pracy i im podobne docierały do naszego polskiego środowiska teologiczno-naukowego i kształtowały powoli prawidłowy punkt widzenia zamierzchłej historii ukrytej w mrokach legend i ruin.

Ks. Ryszard Groń - Chicago, USA

\section{Richard J. FOSTER - Gayle D. BEEBE, Longing for God. Seven paths of Christian Devotion, Downers Grove Il. 2009, Inter Varsity Press, ss. 349.}

Autor Gayle Beebe szczęśliwy, że dzięki kilku ludziom (m. in. Richardowi Fosterowi) spotkał na swojej drodze życia Boga, postanowił podzielić się tym doświadczeniem, i w obliczu wielu egzystencjalno-filozoficznych pytań, które przez lata zadawali mu znajomi i przyjaciele, odpowiedzieć praktycznymi drogami duchowości chrześcijańskiej. Są to w rzeczywistości wykłady obydwu autorów: Richarda Fostera i Gayle Beebe, jakie dali po raz pierwszy na Uniwersytecie 